\title{
КАТАЛИТИЧЕСКИЙ СИНТЕЗ АМИДОВ И АМИДИНОВ РЯДА АДАМАНТАНА С ИСПОЛЬЗОВАНИЕМ ТРИХЛОРИДА ФОСФОРА
}

\author{
Т.Л.К.Во, Е.В. Шишкин \\ Кафедра ТОНС, Волгоградский государственный технический университет, \\ 400005, Россия, г. Волгоград, пр. Ленина, д. 28.
}

DOI: 10.19163/MedChemRussia2021-2021-29

E-mail: voquyen249@gmail.com

В последнее время производные адамантана привлекают большое внимание в связи с их фармакологической активностью и теоретическим интересом для химиковоргаников. Включение адамантанового фрагмента в молекулы различных биологически активных соединений значительно изменяет их фармакологическое действие [1].

В большинстве методов амиды 1-адамантанкарбоновой кислоты получают из 1-адамантанкарбоновой кислоты в две стадии через хлорангидриды, которые легко гидролизуются в присутствии влаги [2]. Нами предложен новый метод синтеза амидов 1-адамантанкарбоновой кислоты в одну стадию с помощью $\mathrm{PCl}_{3}$ в присутствии катализатора DMAP акцептора хлористого водорода триэтиламина при мольном соотношении AdCOOH: $\mathrm{PCl}_{3}$ : амин: DMAP: $\mathrm{Et}_{3} \mathrm{~N}=1: 1: 1: 1: 1$ при температуре $80^{\circ} \mathrm{C}$ в течение 24 . Амиды получены с высокими выходами 62-94\%.

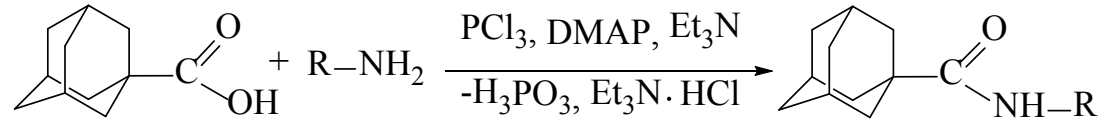

где $R=P h, p-B u P h, m-N O 2 P h, p-N O 2 P h, p-B r P h, p-C l P h, o-M e P h, m-M e P h, p-M e P h, p-M e O P h$

Также нами предложен новый однореакторный метод получения адаманитилсодержащих амидинов из 1-адамантанкарбоновой кислоты с помощью $\mathrm{PCl}_{3}$ в присутствии катализатора DMAP при мольном соотношении $\mathrm{AdCOOH}: \mathrm{PCl}_{3}$ : DMAP: амин: $\mathrm{Et}_{3} \mathrm{~N}=1: 1,5: 1,5: 3: 1:$ при температуре $80^{\circ} \mathrm{C}$ в течение 4ч. Амидины получены с высокими выходами 78-95\%.

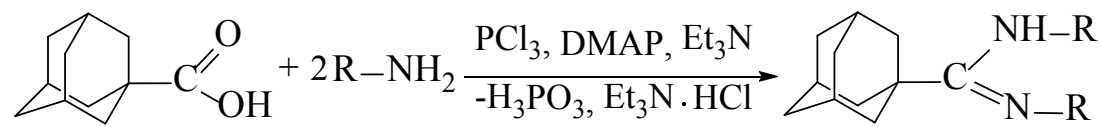
где $R=0-\mathrm{MePh}, \mathrm{M}-\mathrm{MePh}, \mathrm{p}-\mathrm{MePh}, \mathrm{p}-\mathrm{ClPh}, \mathrm{p}-\mathrm{MeOPh}, \mathrm{o}-\mathrm{PrPh}$

Разработанный однореакторный метод синтез амидинов является более эффективным по сравнению с традиционными способами в четыре стадии, поскольку осуществляется без выделения промежуточных продуктов хлорангидридов карбоновых и имидовых кислот, которые легко гидролизуются в присутствии влаги.

\section{Литература}

[1] Морозов И.С., Петров В.И., Сергеева С.А. Фармакология адамантанов, Волгоград: Волгоградская мед. Академия. 2001, - 320 с.

[2] Zhong X., Guo J., Fu S., Zhu D., Peng J. Journal of Surfactants and Detergents. 2014, 17, 943-950. 